\title{
Article
}

\section{Intergroup conflict management strategies from a nobel peace laureate: The case of Jose Ramos-Horta}

Filho, Edson and Rettig, J.

Available at http://clok.uclan.ac.uk/15284/

Filho, Edson ORCID: 0000-0002-8548-4651 and Rettig, J. (2016) Intergroup conflict management strategies from a nobel peace laureate: The case of Jose Ramos-Horta. Basic and Applied Social Psychology, 38 (6). pp. 351-361. ISSN 0197-3533

It is advisable to refer to the publisher's version if you intend to cite from the work. http://dx.doi.org/10.1080/01973533.2016.1221348

For more information about UCLan's research in this area go to http://www.uclan.ac.uk/researchgroups/ and search for <name of research Group>.

For information about Research generally at UCLan please go to http://www.uclan.ac.uk/research/

All outputs in CLoK are protected by Intellectual Property Rights law, including Copyright law. Copyright, IPR and Moral Rights for the works on this site are retained by the individual authors and/or other copyright owners. Terms and conditions for use of this material are defined in the policies page.

\section{CLoK}

Central Lancashire online Knowledge www.clok.uclan.ac.uk

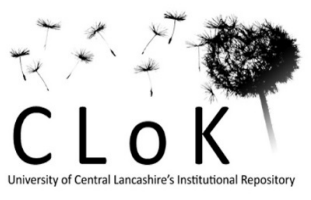


Intergroup Conflict Management Strategies from a Nobel Peace Laureate:

The Case of José Ramos-Horta

Edson Filho ${ }^{1}$, Jean Rettig ${ }^{2}$

${ }^{1}$ School of Psychology, University of Central Lancashire, Darwin Building, Preston, Lancashire, PR1 2HE (UK)

${ }^{2}$ College of Education, Florida State University (USA)

**ACCEPTED FOR PUBLICATION ON AUGUST 4, 2016** 


\begin{abstract}
We report on the case of Dr. José Ramos-Horta (JRH), a 1996 Nobel Peace Laureate, former President of East Timor, and current envoy of the United Nations to Guinea-Bissau. JRH agreed to an interview detailing the peace building strategies he has used to manage conflicts. The transcript of his Nobel Laureate acceptance speech was also analysed to strengthen the overall narrative. Our findings suggest two higher-order themes: (1) psycho-social skills, and (2) social networking. Specifically, JRH uses active listening, mindful breaks, and awareness of media trends to create personal and strategic networking contacts, which are critical elements in managing conflict.
\end{abstract}

Keywords: Intergroup Relations; Political Psychology; Group Processes. 


\section{Intergroup Conflict Management Strategies from a Nobel Peace Laureate: The Case of José Ramos-Horta}

Research on leadership across areas of human interest has centered on correlational studies aimed at identifying population trends and "regression to the mean" effects (for a review see Hiller, DeChurch, Murase, \& Doty, 2011). Most research on leadership has been based on either archival data (e.g., company databases) or cross-sectional survey assessments of individuals at midline managerial roles (Hiller et al., 2011; Rowe, 2001; Zaccaro \& Klimoski, 2001). Accordingly, scholars have emphasized the need to conduct qualitative case assessments of leaders in top managerial positions (Ariño \& Ring, 2010; Sosik, Jung, Berson, Dionne, \& Jaussi, 2005; Zaccaro \& Klimoski, 2001).

The report presented herein, which originated from a unique opportunity to interview a Nobel Peace Laureate, offers a preliminary account of how case outlooks of high-level leaders may aid in the development of leadership theory and practice. We present the selfperceived strategies used by Dr. José Ramos-Horta (JRH) to manage conflicts in East Timor and around the world. In addition to his interview, we conducted a document analysis of his acceptance speech for the Nobel Laureate Prize (The Nobel Peace Prize; see http://www.nobelprize.org/nobel_prizes/peace/laureates/1996). Case studies are particularly telling if considered within a microstoria perspective, wherein present and past views of a subject matter are taken into consideration to create a narrative of a given phenomenon (Boje, 2001; Boje, Haley, \& Saylors, 2016). In this case, our narrative pertained to JRH's conflict management strategies. Given that JRH was awarded the Nobel Peace Prize in the field of "negotiation", we framed our study within the strategic view of leadership, which describes the importance that individuals hold in skillfully negotiating changes to promote improvement in society (Nutt \& Backoff, 1993; Raisch \& Birkinshaw, 2008; Zaccaro \& Klimoski, 2001). 


\section{Strategic Leadership}

Research on strategic leadership is a contemporary development in leadership theory and practice (for a review see Haslam, Reicher, \& Platow, 2010). In contrast to classic (e. g., trait and behavioural theories) and more recent accounts of leadership (e.g., transactional and transformational frameworks), both which are based on the "leader-follower" dichotomy, strategic leadership reflects a "system" view in the sense that the leadership phenomena is explained through the interactions of members inside and outside a given context (Boal \& Schultz, 2007; Crossan, Vera, \& Nanjad, 2008; Furrer, Tjemkes, \& Henseler, 2012).

Strategic leaders' degree of influence is at the macro (i.e., organizational), rather than meso (i.e., departmental teams) or micro (i.e., individual followers) level of analysis (Vera \& Crossan, 2004). This is not to suggest that strategic leaders are "larger than life individuals", but rather to indicate that strategic leaders must develop and engage adaptive strategic behaviours (Boal \& Schultz, 2007; Gavetti, 2011). Such behaviours are aimed at (a) creating high-value networking opportunities that allow for organizational growth, and (b) managing "inside-out"/exploration and "outside-in"/exploitation paradoxes in order to prevent conflict and promote positive change (see Lewis, Andriopoulos, \& Smith, 2013). In this context, scholars have explored strategic leadership by combining myriad theoretical stances and, most noticeably, social network concepts and the exploration-exploitation paradox (see Albers, Wohlgezogen, \& Zajac, 2013; Ariño \& Ring, 2010; Elenkov, Judge, \& Wright, 2005; Jansen, Vera, \& Crossan, 2009; O'Reilly \& Tushman, 2011; Smith \& Tushman, 2005; Sosik et al., 2005; Vera \& Crossan, 2004). The current understanding is that strategic leadership is a systemic process that should be studied through multiple theoretical lenses (Lin \& Darnall, 2015; Meng, 2012).

Strategy and Social Networking. It is generally recognized that one cannot lead radical change by oneself (Helfat \& Martin, 2015). As such, strategic leaders actively seek 
constructive networking opportunities to allow for organizational growth towards "desired states" or "next-generation models" (Lin \& Darnall, 2015). Strategic leaders are interested in augmenting their network value by increasing the size of their social capital and strengthening the intensity of existing personal and professional connections (see Tasselli, Kilduff, \& Menges, 2015). The size of a network can be enhanced by (a) developing new relationships with established stakeholders, or (b) recognizing future trends to gain the socalled "first movers advantage" in occupying central network positions (Cullen, Gerbasi, \& Chrobot-Mason, 2015; Fuentelsaz, Garrido, \& Maicas, 2013). The intensity of a network is not about leveraging new connections but rather about increasing network flux. To enhance network intensity one must reinforce existing interconnecting links. In practice, a strategic leader can only facilitate organizational development if s/he invests, through continuous communication and interaction, in existing connections (Ariño \& Ring, 2010; Fuentelsaz et al., 2013). Networking within and outside of an organizational context is also important in developing strategic leaders' abilities to deal with management paradoxes.

Strategy and the Exploration-Exploitation Paradox. Strategic leadership involves managing inside-out and outside-in paradoxes, also known as the exploration-exploitation dichotomy (see Raisch \& Birkinshaw, 2008). Strategic leaders must simultaneously exploit current status quo practices and modes of thinking, while exploring novel practices and seeking creative ways of thinking (Jansen et al., 2009). For instance, in large corporations, CEOs must often decide whether to expand on a previously established product or invest in the development of new intellectual property (Daily, McDougall, Covin, \& Dalton, 2002). In high-stakes politics, diplomats must leverage insiders' beliefs with outsiders' views in order to find a peaceful resolution for social, ethnic, and warfare conflicts and paradoxes (Lewis et al., 2013). In fact, several individuals have been awarded Nobel Peace Prizes for their ability to strategically manage paradoxical beliefs and mixed-motive ventures across societal groups. 


\section{The Present Case}

Our purpose was to elicit the strategies adopted by JRH to manage conflict during his tenure as a social activist, diplomat and politician. Drawing from the literature, we were interested in his strategic leadership behaviour in managing conflict around the world. The overarching research questions were: (a) What strategies have you adopted to make peaceful connections around the world? and (b) What strategies have you used to manage conflicts around the world?

\section{Methods}

\section{Participant}

JRH agreed to be interviewed and provided verbal and written consent indicating that his participation was voluntary and allowing his name to be used in this manuscript. At the time of the study, JRH was 64 years old and the envoy of the United Nations secretary general to Guinea-Bissau. JRH has had a distinguished political career and recently finished his term as President of East Timor (2007-2012). His most significant award was the Nobel Peace Prize in 1996, which he shared with Carlos Filipe Ximenes Belo "for their work towards a just and peaceful solution to the conflict in East Timor" (The Nobel Peace Prize; see http://www.nobelprize.org/nobel_prizes/peace/laureates/1996/).

\section{Data Collection}

Data collection consisted of an interview that lasted approximately 30 minutes and document analysis of JRH's Nobel Laureate acceptance speech, which is a publicly available document (https://www.nobelprize.org/nobel_prizes/peace/laureates/1996/ramos-hortalecture.html).

Interview. The interview was video recorded and occurred at a date, time, and place chosen by JRH. The opportunity to interview JRH was mediated by the organizational committee of the Lindau Nobel Laureate Meetings. This committee organizes annual 
meetings to promote interactions between Nobel Laureates from all fields (e.g., Chemistry, Economic Sciences, Literature, Medicine, Peace and Physics) and early career researchers.

The interview guide consisted of the two research questions. The intention was to have general orienting questions while maintaining a flexible approach to the interview. Such an approach reflects a constructivist stance, wherein an individual is invited to construct (and re-construct) his/her individual experiences (Charmaz, 2006; Lincoln \& Guba, 2000; Mills, Bonner, \& Francis, 2006). The actual probe asked at the beginning of the interview was: "I would like to hear from you about your experience in making peaceful connections around the world". A follow-up question consisted of: "You just took us through history, mentioning your personal history... I wonder how you connect with people on a personal level... what is your personal strategy that helps you to make these peaceful connections?" The interview continued with minimum interference from the interviewer as the idea was to allow JRH the ability to speak as freely and as much as possible. This approach is consistent with extant research suggesting that high-functioning individuals are more likely to access their metacognitive schemas, therefore constructing and re-constructing pathways to their expertise, when allowed to speak freely with minimal interruption (Ericsson \& Simon, 1998).

Nobel Laureate acceptance speech. The transcript of JRH's Nobel Laureate acceptance speech was used as supplementary material to the data generated from the interview. Reviewing past documented events contributes to "retrospective sensemaking" within a microstorical ontological stance (Boje, 2001). Microstoria analysis provides rich ontological material on one's life story, as past events are meaningfully linked to the present and likely repeated in the future (Bakhtin, 2010; Boje, 2001; Boje, Haley, \& Saylors, 2016). In other words, microstorical analysis allows for the identification of general trends of one's life story. In particular, retrospective sensemaking of historical events may help to reveal consistent traits of individuals' microstoria. Boje et al. (2016) noted that microstoria is an 
fitting methodology for examining leaders' strategic decisions as managers usually “justify future obligations through retrospective sensemaking" (p. 397). Thus, the analysis of JRH's Nobel Laureate acceptance speech within a microstoria ontological stance was conducted in an attempt to enrich the data interview, thereby creating a "grand narrative" of JRH's idiosyncratic strategies to manage intergroup conflicts.

JRH's Nobel Laureate acceptance speech was presented at the Peace Prize Ceremony in 1996, and the transcript is available to the public online. A Google search on "José RamosHorta" returned over 379,000 entries (June 2016), and therefore the selection of this document relied on the criteria put forth by Bowen (2009). Specifically, JRH's Nobel Laureate was representative of the research questions proposed in the study. Furthermore, this speech was selected for analysis because of its (a) authenticity in portraying JRH's opinions on peace, as the content was written and delivered by JRH; (b) stability, as the document has verified historical facts that have been catalogued by the Nobel Laureate Committee; and (c) availability, as the document is a public record available on the internet.

\section{Data Analysis}

The interview data was coded using thematic analysis, as our goal was to inductively identify themes and sub-themes pertaining to JRH's self-perceived conflict management strategies. For the analysis of JRH's Nobel Laureate acceptance speech, we employed a deductive approach through content analysis, based on the themes previously identified from the interview data, as our goal was to look for potential historical roots or "unchanging traits" of JRH's conflict management strategies.

Interview. Themes were coded inductively based on Braun and Clarke's (2006) theoretical thematic analysis and categorized deductively with respect to the aforementioned social network and the exploration-exploitation conceptual accounts of strategic leadership. This analytical approach is congruent with the importance of engaging in "interpretative 
pluralism" in qualitative and leadership research (see Kincheloe, 2005; Lin \& Darnall, 2015; Meng, 2012; Tenenbaum \& Filho, 2015). The analytical process consisted of six steps: (1) familiarization with the data, (2) generating initial codes, (3) searching for themes, (4) reviewing themes, (5) defining and naming themes, and (6) producing the report (Braun \& Clarke, 2006). Data analysis commenced with the leading author reading and re-reading the transcription of the interview until he became familiar with the raw data. Next, the leading author segmented the verbatim transcription into meaning units of text. In the third step, the leading author grouped these meaningful units of text, by similarity of meaning, into themes taking into consideration both the social network and the exploration-exploitation accounts of strategic leadership. These grouped meaning units were then independently reviewed by the second author. The inter-rater kappa coefficient between the first and last author at this stage of the analysis was .86. The meaning units that needed recoding and re-grouping were identified and discussed until full consensus was reached. Once this process was completed, an independent external auditor with training in qualitative methodology was asked to review the analysis. In the fifth step, names for the refined themes were defined, based on input from all authors, and quotes capturing the essence of each theme were identified. Finally, the results were elaborated on within the manuscript write-up and described in terms of coherence. A thematic map was generated to visually illustrate the results.

Nobel Laureate acceptance speech. JRH's acceptance speech was analysed through direct categorical analysis, which consists of a deductive approach of searching for predetermined categories (see Elo \& Kyngäs 2008; Hsieh \& Shannon, 2005). As alluded to previously, it was our expectation that analyzing JRH's historical speech in relation to his current self-perceived conflict management strategies garnered from the interview would allow for the development of a broader narrative. Moreover, Elo and Kyngäs (2008) recommend the use of direct categorical analysis, to complement other data collected in the 
same study, to aid the overall trustworthiness of the findings. In the present study, the predetermined categories used for the direct categorical analysis of the acceptance speech consisted of the themes and sub-themes identified in the interview data from JRH.

The coding process consisted of a number of steps, as outlined by Hsieh and Shannon (2005). Initially, the first and last authors independently read and re-read the verbatim transcripts of JRH's acceptance speech until they became familiar with the data. Subsequently, they independently searched for meaning units reflecting the pre-defined codes (i.e., themes and sub-themes from the interview data). A total of 9 meaning units were initially identified by both coders. The inter-rater kappa coefficient was .72 . The first and last author then discussed these meaning units until 100\% agreement was reached, for a total of 9 meaning units. Finally, several quotes were selected and elaborated on within the manuscript write-up.

Trustworthiness. Reliability, or trustworthiness within a naturalistic paradigm (see Lincoln \& Guba, 1985; 2000; Patton, 2002), was established through data analysis triangulation. Specifically, member checking, independent data coding, peer debriefing meetings among the authors, the use of an external researcher as an auditor, and supplementary document analysis were included as part of the data analysis in order to maximize reliability. First, member checking was conducted to ensure that the data was transcribed verbatim (Guba \& Lincoln, 1989). The quotes from the interview were emailed to $\mathrm{JRH}$, and he had the opportunity to review them. In this regard, JRH requested to change the names of places and people mentioned in the interview to general descriptors (i.e., "X", "Y", and "Z"), and provided clarifications regarding some of his comments. The data analysis also involved independent data coding by the first and last author, followed by peer debriefing discussions until consensus was reached. The thematic analysis was based on an interpretative pluralist approach wherein different accounts of strategic leadership were 
juxtaposed. Moreover, an external researcher was asked to review the thematic analysis by serving as a "critical friend" in providing constructive feedback on the data analysis (see Kember et al., 1997). Finally, direct content analysis of a supplementary document (i.e., JRH's Nobel Laureate acceptance speech) was also conducted in an attempt to increase the overall trustworthiness of the findings.

\section{Results}

Our analysis resulted in two higher order themes: (1) Psycho-Social Skills, and (2) Social Networking. Each theme was underlined by different sub-themes as described next, and exemplified by quotes from JRH's interview and Nobel Laureate acceptance speech. Psycho-social skills and social networking seem to be inter-related in a systemic fashion as depicted in Figure 1.

\section{Psycho-Social Skills}

Psycho-social skills enabled JRH to be successful in managing societal conflicts. In particular, three skills were identified from the interview: (1) active listening, (2) mindful breaks, and (3) awareness of media trends.

Active Listening. Active listening consists of making a conscious effort to carefully consider and empathize with others' verbal and non-verbal messages during conversations. JRH discourse suggested that there is a quantitative and qualitative feature to active listening. To him, active listening involves "listen[ing] more than talking" and "listen[ing] attentively...not pretending to listen".

It is always difficult to listen, because many people have the tendency of more talking, of listening to their own voice, to their own opinion... but I would say that successful leaders and learners are the ones who are very patient listeners. (Interview Excerpt)

To better communicate you have to know how to listen. Listening attentively, not pretending to listen...because some people are listening to you but they are not actually listening. They are already, in their mind, answering their own questions even before a person finishes his line of thought. So it is tremendously important to be a patient listener. (Interview Excerpt) 
Document analysis of JRH's Nobel Laureate acceptance speech suggested that he

valued active listening in political mediation.

It was sometime in early 1991 and I was driving from the small Swiss town of Nyon, to the Palais des Nations in Geneva, to yet another round of futility in a place where some diplomats pretend to be too busy to listen to real problems of real peoples. (Nobel Laureate acceptance speech)

Mindful Breaks. Mindfulness is a multi-layered meta-cognitive process that includes a state of non-judgment and attentional focus directed to the present (see Riskin, 2004; 2009). The facet of mindfulness emphasized by JRH involved intentionally taking a break to clear the mind to a state of calm awareness. Mindful breaks consisted of acknowledging and choosing to break from "negative cognitive-emotional-behavioural cycles". Mindful breaks appeared particularly important when a dialogue involved continuous retaliation ("Tit-forTat") among two or more parties in a confliction situation.

In the needs of the intensity of the war, of this conflict, it is so difficult to engage in dialogue. I give an example of how I recently managed a difficult situation in ' $X$ '. One afternoon I got a phone call from a political leader who was very angry, shouting over the phone against the President of that country... saying tomorrow there will be a political crisis. I was listening and listening... Then I said 'okay, can I come to see you tonight?". Of course he said yes. So I went to see the President. I listened to him, and then I went to see the political leaders. It was a Thursday night and I told them tomorrow, Friday, is a Muslin day. In that particular country most people are Muslims but there are Christians and Protestants too. So tomorrow is Friday, a Muslim day, so why don't we all observe that day with no meeting, no fighting, and no negotiations. Saturday and Sunday let's honour the Catholics and Christians, also no meetings, everybody calm down, go to the Mosque, go to the church, the beach, be with family. I don't want to hear anything about politics. Monday we talk. So they had fun during the weekend and they forget about politics for a while. By Monday everybody was calm and we were able to talk more rationally. (Interview Excerpt)

I found with them a solution for that particular, potentially very harmful, political dispute. So sometimes we have to find time for dialogue. War must cease for a while, for a week, two weeks, to see whether the different sectarian groups in ' $X$ ' can somehow sit down and find a way out of this conflict. You have fantastic people on the ' $\mathrm{X}$ ' side and on the ' $\mathrm{Z}$ ' side. $\mathrm{I}$ have been there, in ' $\mathrm{X}$ ' and in ' $\mathrm{Z}$ ', but there is no ongoing dialogue. (Interview Excerpt) 
Document analysis of JRH's Nobel Laureate acceptance speech suggested that mindfulness to discuss different ideas for conflict resolution has been an omnipresent trait of JRH.

I can speak for all when I say that we are ready to enter into a process of dialogue with the Indonesian authorities, under the auspices of the United Nations, without preconditions, to explore all possible ideas towards a comprehensive settlement of the conflict. (Nobel Laureate acceptance speech)

Awareness of Media Trends. Awareness of media trends consists of the ability to

anticipate the direction in which media and communication channels are changing.

Accustomed to living in the public eye, JRH described the importance of noticing media

trends, including the current social media phenomenon.

Social media literally took over at least among the young educated people. Back then my main means of communication with the world was trying to get into the big TV channels and Internet in the 1990s. This interconnectedness is making the world smaller, making contacts with people easier. That is why you see these movements in ' $\mathrm{X}$ ' right now, or in ' $\mathrm{Z}$ ' right now, or ' $\mathrm{Y}$ '. (Interview Excerpt)

I remember when I was in ' $\mathrm{X}$ ' talking with a popular politician. He was so frustrated. He said 'why does this NGO have so much power? No one elected them and they have so much power'. And I said, well they are operating a little office, with a little budget, but they know how to work public opinion on social media, and this is becoming an incredible tool. (Interview Excerpt)

The analysis of JRH's Nobel Laureate acceptance speech revealed that his openness

to media trends, particularly how modern electronic communications make the world

"smaller", has been evident from the time he mediated peace talks between East-Timor and

Indonesia.

No country, no matter how rich and endowed with natural resources, is an island unto itself. In an increasingly smaller world and competitive age, where modern electronic communications break the barriers of silence erected by dictators, Indonesia cannot continue to flout the right of the people of East Timor to self-determination and the rule of law in Indonesia. (Nobel Laureate acceptance speech)

\section{Social Network}


The analysis of JRH discourse suggested that he was keen on developing his network by expanding the size of his personal and professional contacts, while also investing time and effort in strengthening previous relationships, akin to the notion of network intensity.

Size. JRH emphasized the importance of expanding his network by "making friends" from different social groups and with both local (e.g., "street vendors") and international (e.g., "kings") spheres of influence. To JRH, expanding his network size led to both strategic and personal benefits, including learning new information and securing strategic connections, as well as gaining personal fulfilment and enjoyment.

Making friends and building blocks of friends, networks of contacts around the world, for your personal fulfilment, enjoyment and learning. Enjoyment in people, in all kinds of people, from A to Z, from a street vendor to a big King. Not all Kings are pleasant, interestingly. Sometimes a street vendor is more interesting than a King. (Interview Excerpt)

You do have to make friends, to contact people, to sit in a conference, in a classroom, in a discussion group, to grow... where else do you get your information from? Information from a computer is not enough if it does not come also through somehow sharing in a discussion with physical people. (Interview Excerpt)

I did it [networking] strategically to build alliances for my country, and this is what actually helped us achieve freedom. We won our battle for independence, for freedom, also thanks to the network that I built over more than twenty years around the world, particularly in ' $\mathrm{X}$, ' $\mathrm{Y}$ ', ' $\mathrm{Z}$ ' ... (Interview Excerpt)

The analysis of JRH's acceptance speech expanded on our inductive thematic

analysis. As far back as 25 years ago, JRH spoke of connecting with people, from different

countries and ethnicities, by finding a common denominator.

From the Chittagon Hill Tracts in Bangladesh to Bougainville, Kurdistan, Sri Lanka, India, Tibet, Chechnya, Ogoni, West Papua, millions of peoples seek to assert their most fundamental rights and if we attempt to find a common denominator for the problems I have just listed there is one: the right of peoples to self-determination. (Nobel Laureate acceptance speech)

Intensity. The importance of continuously strengthening existing relationships was also described by JRH as a key action in political work. In particular, JRH mentioned that he 
invested time in social interactions with local community leaders as well as internationally recognized political and military leaders.

I contact, I write, I respond, to a certain variety of people. Right now I am the special envoy of the United Nations Secretary General in a west African country called Guinea Bissau... that is tango [easy] with all the other problems in west Africa, with the drug cartels of $\mathrm{X}$, particularly Y and Z... and I don't work only with the military there and other political leaders. (Interview Excerpt)

I spend time going to the market, meeting with street vendors, or youth who are into organizing sports events, culture, film festivals, etc... For me, the human factor has to be always taken into consideration at least in my work. (Interview Excerpt)

Analysis of JRH's acceptance speech reinforced the notion that maintaining network

connections with different individuals and organizations has been a long-standing part of his

political approach.

The following year, in April 1975, I again visited Indonesia and met with President Suharto's senior adviser, Gen. Ali Mortopo, to whom I reiterated our collective desire to develop friendly relations with Indonesia. (Nobel Laureate acceptance speech)

We will actively work with like-minded countries, NGOs and the media to strengthen the UN human rights machinery. (Nobel Laureate acceptance speech)

\section{Discussion}

Given that most research in leadership has been nomothetic in nature (Ariño \& Ring, 2010; Hiller et al., 2011; Rowe, 2001; Zaccaro \& Klimoski, 2001), we sought to conduct an in-depth interview to elicit conflict management strategies used by a Nobel Peace Laureate over the course of his political tenure. Our rationale for interviewing JRH was based on evidence suggesting that a single recognized expert often provides more creative insights into his/her subject matter than the collective input of several individuals (Ericsson \& Simon, 1998; Gigerenzer \& Gaissmaier, 2011). Altogether, our findings suggest that JRH has developed a series of psycho-social skills that have enabled him to establish an extensive network with both local and global leaders. This network, in turn, has been important for the development of cooperative arrangements and peaceful solutions for conflicts around the world. 


\section{Psycho-Social Skills}

Our findings suggest that JRH possesses a series of psycho-social skills that allow him to display high-levels of strategic leadership behaviours. In fact, high-performing individuals across domains of human activity develop myriad psycho-social skills that enable them to optimally self-regulate their cognitions, emotions and actions (i.e., cognitiveemotional-behavioural link) in high-pressure situations (see Filho \& Tenenbaum, 2015; Raab, Lobinger, Hoffmann, Pizzera, \& Laborde, 2015). In our analysis, active listening appears to be a crucial skill for individuals involved in managing group conflict. As presented, JRH recognized that it was essential to "listen more than talk" and "listen attentively...not pretend to listen". Indeed, active listening has been linked to fostering empathetic feelings among people while promoting social processes, such as cohesion and shared efficacy beliefs (Fung, Miller, \& Lin, 2004; Hackley, 2007). Active listening has been recognized as a metacognitive psycho-social skill, insofar that one must silence his/her inner emotional dialogue and rational pre-conceptions (or heuristics), while reflecting on the information presented by the speaker (Seden, 2005).

In addition to active listening, the analysis of JRH discourse suggests that taking mindful breaks is a crucial component of his conflict management approach. JRH noted that "War must cease for awhile" so that conflicting groups can "sit down and find a way out". These mindful breaks might be particularly important in changing "tit-for tat" retaliation cycles (Nash equilibrium) to more cooperative strategies that allow for better outcomes for all involved parties (for a review see Brams, 2011). The ability to recognize negative cycles and consciously, yet non-judgmentally, refrain from engaging in destructive actions is at the heart of mindfulness approaches to conflict resolution (Riskin, 2004; Ting-Toomey \& Kurogi, 1998). Moreover, mindful breaks allow for better communication exchanges, which in turn help to de-escalate social conflicts while promoting group coordination (Riskin, 2004; 2009). 
The analysis of JRH discourse also revealed the importance of developing an awareness of media trends in the political field. The collection of current and emerging trends within a discipline has been described as a defining skill of strategic leaders (Gavetti, 2011; Meng, 2012; Sosik et al., 2005). Politicians rely on media to create and disseminate "common knowledge" (i.e., knowledge that is shared by the majority of members within a social network) on sensitive issues (Barabas \& Jerit, 2009). Awareness of emerging trends is also important in the sense that it allows strategic leaders to monitor intra- and inter-group alliance formation, operation and reconfiguration (Ariño \& Ring, 2010; Lin \& Darnall, 2015).

\section{Social Networking}

Our findings also suggest that JRH was cognizant of the importance of expanding the size and intensity of his social network. With respect to network size, our findings echo the notion that managing complex social problems is reached through a collective effort, namely a strategic leadership vision centered on the formation of numerous intra- and inter-group alliances (Furrer et al., 2012; Helfat \& Martin, 2015; Nutt \& Backoff, 1993; Raisch \& Birkinshaw, 2008; Zaccaro \& Klimoski, 2001). In essence, an increase in network size enhances one's ability to receive and transmit information within a given system, hence facilitating the implementation of actions that will result in a lasting impact (Albers et al., 2013; Cullen et al., 2015; Elenkov et al., 2005; Fuentelsaz et al., 2013). Our analysis of JRH discourse revealed his interest in networking with influential regulators in both local and global spheres of influence (e.g., "street vendors and kings"). The importance of connecting with prominent regulators has been epitomized in Pareto's Law, and conceptually captured by the notion of "hubs" in Graph Theory (see Bondy \& Murty, 1976). In line with Graph Theory tenets, a single "hub" may exert more influence on the system than the combination of various less important members. Accordingly, without an extensive network, JRH would 
be less likely to succeed in helping his country achieve freedom, as well as mediate peace talks among conflicting countries.

With respect to network intensity, JRH highlighted the importance of maintaining and strengthening his network ties with both internal and external leaders of different power latitudes (e.g., political and military leaders; youth and community leaders) in order to learn crucial information about on-going societal matters. JRH understood the vital importance of "contacting, writing and responding to a variety of people" in order to manage inter-group conflicts. To this extent, scholars concur that strategic leaders must remain visible to both internal and external community constituents and political stakeholders within a given social network (Boal \& Schultz, 2007; Crossan et al., 2008; Furrer et al., 2012; Meng, 2012; Sosik et al., 2005; Tasselli et al., 2015; Vera \& Crossan, 2004). Without visibility, ones' ability to manage "inside-out"/exploration and "outside-in"/exploitation paradoxes diminishes considerably, particularly in complex adaptive systems such as high-stakes business and political negotiations (Boal \& Schultz, 2007; Jansen et al., 2009; Lewis et al., 2013; O'Reilly \& Tushman, 2011; Raisch \& Birkinshaw, 2008). Investing in relationship building also helps one to readily identify conflict contagion within and between groups (see Jehn, Rispens, Jonsen, \& Greer, 2013). Overall, our findings suggest that strengthening internal and external network ties constituted part of JRH's strategies in dealing with group conflicts.

\section{Implications}

From a theoretical standpoint, our findings relate to current literature on political mediation, particularly the role of super-humanization and de-humanization biases in intergroup conflict (Haslam \& Loughnan, 2014; Waytz, Hoffman, \& Trawalter, 2014). From slavery, to colonization, the holocaust, and current religious and political wars, intergroup conflict is often based on the assumption that "we" (the inner-group super-humans), are better than "them" (the outer-group infra-humans). Perhaps JRH has been able to mediate various 
conflicts around the world because he remained grounded on his humanity - "human" from "humus" meaning soil/earth in Latin. This humanistic approach might have been the reason he was able to listen, be mindful, remain open-minded to new trends, and network with both "kings and street vendors". In fact, strategic leaders often adopt a humanistic approach, as they focus on long-term gains and societal changes (Nutt \& Backoff, 1993; Raisch \& Birkinshaw, 2008; Zaccaro \& Klimoski, 2001).

From a methodological standpoint, it is important to highlight that our findings suggest that JRH's psycho-social skills and emphasis on networking to solve problems has long standing roots. Parts of JRH's Nobel Laureate acceptance speech mirrored greatly his present-day view on conflict management. Thus, we echo the notion that microstoria approaches, particularly those focusing on a retrospective stance as in the present case, can be a powerful tool in advancing knowledge on life narratives among "outlier" individuals in leadership positions (see Boje et al., 2016). After all, studying how high-functioning individuals have evolved to "become" experts in their fields may advance knowledge on the path to expertise in political mediation, and across domains of human interest (for a review see Ericsson, Charness, Feltovich, \& Hoffman, 2006; Raab et al., 2015).

From an applied standpoint, our findings suggest that JRH uses psycho-social skills to manage conflict around the world. Applied psychologists have shown that training in communication and mindfulness facilitates optimal performance in high-pressure situations in various domains, including business, politics, sports and the military (for a review see Filho \& Tenenbaum, 2015; Raab et al., 2015). Accordingly, leaders across domains of human activity may benefit from engaging in mental training programs aimed at developing negotiation skills such as those outlined by JRH (e.g., active listening, mindful breaks, awareness of media trends), or tailored to their specific contextual needs. Leaders aiming for a long-term lasting impact should also seek information and training on social networking. To 
reiterate, our findings suggest that managing complex situations requires collective effort and a strategic vision.

\section{Limitations and Future Research}

Our findings are limited in statistical power. However, qualitative case studies are not designed for statistical generalizability but rather rely on the concept of "transferability" in naturalistic inquiry (see Gephart, 2004). In fact, successful strategies in business are often mirrored by other leaders and companies across varying fields (Ariño \& Ring, 2010). Thus, while the findings might not be generalizable per se, the insights revealed in the case analysis of JRH might be transferable to other natural settings where strategic behaviours and conflict resolution skills are needed and valued. For instance, JRH's strategic implementation of "mindful breaks" could be mimicked by high-stake politicians dealing with paradoxical situations or trying to find a way to establish peace among contentious nations.

Multi-case studies are warranted to provide further insights on how "outliers", such as JRH, manage complex intergroup conflicts in different cultural contexts. Future research comparing idiographic analyses of other outliers in leadership and peace-making can help to advance theoretical and applied knowledge on strategic leadership. In effect, Eisenhardt (1989) has posited that cross-case analysis of information-rich cases can lead to "framebraking" theoretical and applied insights.

Future studies using quantitative approaches might also be fruitful. A series of experimental studies could be conducted to test whether training subjects on the psychosocial strategies identified in JRH discourse could lead to better outcomes in conflict mediation scenarios. Nomothetic approaches using structural equation modelling techniques could be used to examine whether one's psycho-social skills and social network co-evolve, or whether one's skills lead to network growth. That is, while it seems reasonable to suggest that JRH psycho-social skills and social network co-evolved, further research in this area is 
needed to clarify whether "people make the network", "the network makes people", or “people and networks coevolve" (see Tasselli et al., 2015). Finally, our findings are in line with the notion that strategic leadership should be analysed through multiple, rather than single, theoretical lenses. As such, further meta-theoretical work should be conducted to evolve a parsimonious yet integrated model of strategic leadership. 


\section{References}

Albers, A., Wohlgezogen, F., \& Zajac, E. J. (2013). Strategic alliance structures: An organization design perspective. Journal of Management. doi: $10.1177 / 0149206313488209$

Ariño, A., \& Ring, P. S. (2010). The role of fairness in alliance formation. Strategic Management Journal, 31, 1054-1087. doi: 10.1002/smj.846

Bakhtin, M. M. (2010). The dialogic imagination: Four essays (Vol. 1). University of Texas Press.

Barabas, J., \& Jerit, J. (2009). Estimating the causal effects of media coverage on policyspecific knowledge. American Journal of Political Science, 53, 73-89.

Boal, K. B., \& Schultz, P. L. (2007). Storytelling, time, and evolution: The role of strategic leadership in complex adaptive systems. The Leadership Quarterly, 18, 411-428. doi: 10.1016/j.leaqua.2007.04.008

Boje, D. M. (2001). Narrative methods for organizational \& communication research. Thousand Oaks, CA: Sage Publications.

Boje, D. M., Haley, U. C., \& Saylors, R. (2016). Antenarratives of organizational change: The microstoria of Burger King's storytelling in space, time and strategic context. Human Relations, 69, 392-418.

Bondy, J. A., \& Murty, U. S. R. (1976). Graph theory with applications (Vol. 290). Philadelphia, PA: Elsevier.

Bowen, G. A. (2009). Document analysis as a qualitative research method. Qualitative Research Journal, 9, 27-40.

Brams, S. J. (2011). Game theory and politics. North Chelmsford, MA: Courier Corporation. Braun, V., \& Clarke, V. (2006). Using thematic analysis in psychology. Qualitative Research in Psychology, 3, 77-101. doi: 10.1191/1478088706qp063oa 
Charmaz, K. (2006). Constructing grounded theory: A practical guide through qualitative analysis. Thousand Oaks, CA: Sage Publications.

Crossan, M., Vera, D., \& Nanjad, L. (2008). Transcendent leadership: Strategic leadership in dynamic environments. The Leadership Quarterly, 19, 569-581. doi:

10.1016/j.leaqua.2008.07.008

Cullen, K. L., Gerbasi, A., \& Chrobot-Mason, D. (2015). Thriving in central network positions: The role of political skill. Journal of Management. doi: $10.1177 / 0149206315571154$

Daily, C. M., McDougall, P. P., Covin, J. G., \& Dalton, D. R. (2002). Governance and strategic leadership in entrepreneurial firms. Journal of Management, 28, 387-412. doi: 10.1177/014920630202800307

Eisenhardt, K. M. (1989). Building theories from case study research. Academy of Management Review, 14, 532-550.

Elenkov, D. S., Judge, W., \& Wright, P. (2005). Strategic leadership and executive innovation influence: An international multi-cluster comparative study. Strategic Management Journal, 26, 665-682. doi: 10.1002/smj.469

Elo, S., \& Kyngäs, H. (2008). The qualitative content analysis process. Journal of Advanced Nursing, 62, 107-115.

Ericsson, K. A., \& Simon, H. A. (1998). How to study thinking in everyday life: Contrasting think-aloud protocols with descriptions and explanations of thinking. Mind, Culture, \& Activity, 5, 178-186. doi:10.1207/s15327884mca0503_3

Ericsson, K. A., Charness, N., Feltovich, P. J., \& Hoffman, R. R. (Eds.). (2006). The Cambridge handbook of expertise and expert performance. Cambridge University Press.

Filho, E., \& Tenenbaum, G. (2015). Sports psychology. Oxford Bibliographies. Oxford, 
United Kingdom: Oxford University Press. doi: 10.1093/OBO/9780199828340-0175

Fuentelsaz, L., Garrido, E., \& Maicas, J. P. (2013). A strategic approach to network value in network industries. Journal of Management, 41, 864-892. doi:

$10.1177 / 0149206312448399$

Fung, H., Miller, P. J., \& Lin, L. C. (2004). Listening is active: Lessons from the narrative practices of Taiwanese families. Family stories and the life course: Across time and generations, 303-323.

Furrer, O., Tjemkes, B., \& Henseler, J. (2012). A model of response strategies in strategic alliances: A PLS analysis of a circumplex structure. Long Range Planning, 45, 423450. doi: 10.1016/j.lrp.2012.10.003

Gavetti, G. (2011). The new psychology of strategic leadership. Harvard Business Review, 89, 118-125.

Gephart, R. P. (2004). Qualitative research and the Academy of Management Journal. Academy of Management Journal, 47, 454-462.

Gigerenzer, G., \& Gaissmaier, W. (2011). Heuristic decision making. Annual Review of Psychology, 62, 451-482. doi: 10.1146/annurev-psych-120709-145346

Guba, E. G., \& Lincoln, Y. S. (1989). Fourth generation evaluation. Newbury Park, CA: Sage Publications.

Hackley, S. (2007). One reasonable and inquiring man: 12 angry men as a negotiationteaching tool. Negotiation Journal, 23, 463-468. doi:10.1111/j.15719979.2007.00157.x

Haslam, N., \& Loughnan, S. (2014). Dehumanization and infrahumanization. Annual Review of Psychology, 65, 399-423.

Haslam, S. A., Reicher, S. D., \& Platow, M. J. (2010). The new psychology of leadership: Identity, influence and power. Abingdon, England: Psychology Press. 
Helfat, C. E., \& Martin, J. A. (2015). Dynamic managerial capabilities: Review and assessment of managerial impact on strategic change. Journal of Management, 41, 1281-1312. doi: $10.1177 / 0149206314561301$

Hiller, N. J., DeChurch, L. A., Murase, T., \& Doty, D. (2011). Searching for outcomes of leadership: A 25-year review. Journal of Management. doi: 10.1177/0149206310393520

Hsieh, H. F., \& Shannon, S. E. (2005). Three approaches to qualitative content analysis. Qualitative Health Research, 15, 1277-1288.

Jansen, J. J. P., Vera, D., \& Crossan, M. (2009). Strategic leadership for exploration and exploitation: The moderating role of environmental dynamism. Leadership and Organizational Learning, 20, 5-18. doi:10.1016/j.leaqua.2008.11.008

Jehn, K., Rispens, S., Jonsen, K., \& Greer, L. (2013). Conflict contagion: a temporal perspective on the development of conflict within teams. International Journal of Conflict Management, 24, 352-373.

Kember, D., Ha, T. S., Lam, B. H., Lee, A., Ng, S., Yan, L., \& Yum, J. C. (1997). The diverse role of the critical friend in supporting educational action research projects. Educational Action Research, 5, 463-481. doi: 10.1080/09650799700200036

Kincheloe, J. (2005). On to the next level: continuing the conceptualization of the bricolage. Qualitative Inquiry, 11, 323-350. doi: 10.1177/1077800405275056

Lewis, M. W., Andriopoulos, C., \& Smith, W. K. (2013). Paradoxical leadership to enable strategic agility. California Management Review, 56, 58-77. doi: $10.1525 / \mathrm{cmr} .2014 .56 .3 .58$

Lin, H., \& Darnall, N. (2015). Strategic alliance formation and structural configuration. Journal of Business Ethics, 127, 549-564. doi: 10.1007/s10551-014-2053-7 
Lincoln, Y. S., \& Guba, E. G. (1985). Naturalistic inquiry (Vol. 75). London, UK: Sage Publications.

Lincoln, Y. S., \& Guba, E. G. (2000). Paradigmatic controversies, contradictions, and emerging confluences. In N. Denzin \& Y. Lincoln (Eds.), Handbook of qualitative research (pp.163-188). London, UK: Sage Publications.

Meng, J. (2012). Strategic leadership in public relations: An integrated conceptual framework. Public Relations Review, 38, 336-338. doi: 10.1016/j.pubrev.2012.01.004

Mills, J., Bonner, A., \& Francis, K. (2006). Adopting a constructivist approach to grounded theory: Implications for research design. International Journal of Nursing Practice, $12,8-13$.

Nutt, P. C., \& Backoff, R. W. (1993). Transforming public organizations with strategic management and strategic leadership. Journal of Management, 19, 299-347. doi: 10.1016/0149-2063(93)90056-S

O'Reilly III, C. A., \& Tushman, M. L. (2011). Organizational ambidexterity in action: How managers explore and exploit. California Management Review, 53, 5-22.

Patton, M. Q. (2002). Qualitative research and evaluation methods (3rd ed.). Thousand Oaks, CA: Sage Publications.

Raab, M., Lobinger, B., Hoffmann, S., Pizzera, A., \& Laborde, S. (Eds.). (2015). Performance psychology: Perception, action, cognition, and emotion. Cambridge, MA: Academic Press.

Raisch, S., \& Birkinshaw, J. (2008). Organizational ambidexterity: antecedents, outcomes, and moderators. Journal of Management, 34, 375-409.

Riskin, L. L. (2004). Mindfulness: Foundational training for dispute resolution. Journal of Legal Education, 54, 79.

Riskin, L. L. (2009). Awareness and ethics in dispute resolution and law: Why mindfulness 
tends to foster ethical behavior. South Texas Law Review, 50.

Rowe, W. G. (2001). Creating wealth in organizations: The role of strategic leadership. The Academy of Management Executive, 15, 81-94.

Seden, J. (2005). Counselling skills in social work practice. London, UK: McGraw-Hill Education.

Smith, W., \& Tushman, M. (2005). Managing strategic contradictions: A top management model for managing innovation streams. Organization Science, 16, 522-536. doi: 10.1287/orsc.1050.0134

Sosik, J. J., Jung, D. I., Berson, Y., Dionne, S. D., \& Jaussi, K. S. (2005). Making all the right connections: The strategic leadership of top executives in high-tech organizations. Organizational Dynamics, 34, 47-61. doi: 10.1016/j.orgdyn.2004.11.003

Tasselli, S., Kilduff, M., \& Menges, J. I. (2015). The microfoundations of organizational social networks: A review and an agenda for future research. Journal of Management, 41, 1361-1387. doi: 10.1177/0149206315573996

Tenenbaum, G., \& Filho, E. (2015). Measurement considerations in performance psychology. In M. Raab, B. Lobinger, S. Hoffmann, A. Pizzera, \& S. Laborde (Eds.), Performance psychology: Perception, action, cognition, and emotion (pp. 31-44). Cambridge, MA: Academic Press.

The Nobel Peace Prize. (1996). Retrieved from http://www.nobelprize.org/nobel_prizes/peace/laureates/1996/.

Ting-Toomey, S., \& Kurogi, A. (1998). Facework competence in intercultural conflict: An updated face-negotiation theory. International Journal of Intercultural Relations, 22 , $187-225$.

Vera, D., \& Crossan, M. (2004). Strategic leadership and organizational learning. The Academy of Management Review, 29, 222-240. 
Waytz, A., Hoffman, K. M., \& Trawalter, S. (2014). A superhumanization bias in whites' perceptions of blacks. Social Psychological and Personality Science, 1948550614553642.

Zaccaro, S. \& Klimoski, R. (2001). The nature of organizational leadership. San Francisco, CA: Jossey-Bass. 